Journal of Epidemiology and Public Health (2017), 2(2): 174-185

https://doi.org/10.26911/jepublichealth.2017.02.02.08

\title{
Sanitation-Related Behavior, Container Index, and Their Associations with Dengue Hemorrhagic Fever Incidence in Karanganyar, Central Java
}

\author{
Nunik Maya Hastuti',2), Ruben Dharmawan3), Dono Indarto4) \\ 1)School of Health Sciences Mitra Husada, Karanganyar, Central Java \\ ${ }^{2)}$ Masters Program in Public Health, Universitas Sebelas Maret \\ 3)Deparment of Parasitology, Faculty of Medicine, Universitas Sebelas Maret \\ 4)Department of Physiology, Faculty of Medicine, Universitas Sebelas Maret
}

\begin{abstract}
Background: Dengue Hemorrhagic Fever (DHF) causes not only epidemic but also social and economic impacts. Environmental sanitation, water reservoirs, and community behavior can influence the incidence of DHF. This study aimed to examine sanitation-related behavior, container index, and their associations with dengue hemorrhagic fever incidence.

Subjects and Method: This was an analytic observational field study using case control design. The study was conducted in sub-districts with the highest and lowest DHF cases in Karanganyar, Central Java, from May to July 2017. A total sample of 120 study subjects was selected for this study using fixed disease sampling, including 40 people with DHF and 80 people without DHF. The dependent variable was DHF. The independent variables were age, education level, family income, container index, and sanitation behavior. The data were measured by a set of questionnaire and examined using path analysis.

Results: Sanitation behavior $(b=1.50 ; 95 \% \mathrm{CI}=0.57$ to $2.42, \mathrm{p}=0.001)$ and Container Index $(\mathrm{b}=$ $0.90 ; 95 \% \mathrm{CI}=0.03$ to $1.84 ; \mathrm{p}=0.057$ ) were directly and positively associated with DHF incidence. Container Index was associated with sanitation behavior $(b=2.09,95 \% \mathrm{CI}=1.21$ to $2.97, \mathrm{p}<0.001)$. Age $(b=-0.76,95 \% \mathrm{CI}=-1.60$ to $0.08, \mathrm{p}=0.074)$, education level $(\mathrm{b}=-1.02,95 \% \mathrm{CI}=-1.87$ to -0.17 , $\mathrm{p}=0.019)$, and family income $(\mathrm{b}=-0.70,95 \% \mathrm{CI}=-1.60$ to $0.19, \mathrm{p}=0.122)$ were associated with sanitation behavior.

Conclusion: DHF incidence is directly and positively associated with sanitation behavior, and container index. DHF incidence is indirectly associated with age, education level, and family income.
\end{abstract}

Keywords: dengue haemorhagic fever, sanitation, container index, behavior, path analysis

\section{Correspondence:}

Nunik Maya Hastuti. School of Health Science Mitra Husada, Karanganyar, Central Java. Email: nunikmaya21@gmail.com. Mobile: +6285647279291.

BACKGROUND
Dengue Hemorrhagic Fever (DHF) is a dis-
ease that has become a global problem in
most tropical and subtropical regions. The
incidence rate and geographical area of the
distribution of DHF over the past 50 years
have increased 30-fold with increasing geo-
graphical expansion to new countries
(WHO, 2009). A study by Bhatt et al.
(2013) reported that cases of dengue fever
were far more than what WHO has estima-

ted and indicated that 390 million dengue virus infections could occur every year.

According to WHO (2016), before 1970, only 9 countries experienced severe epidemics of dengue hemorrhagic fever cases but are currently endemic cases in more than 100 countries in WHO region namely Africa, America, the Eastern Mediterranean, Southeast Asia and the Western Pacific.

Areas in America, Southeast Asia and Western Pacific are the ones with the most 
serious cases. In 2008 dengue cases throughout America, Southeast Asia and the Western Pacific exceeded 1.2 million and more than 3.2 million in 2015. In 2015, there were 2.35 million dengue cases reported by people in America. Of the 10,200 cases, 1,181 of them caused death (WHO, 2016).

DHF has been a public health problem in Indonesia since 1968. There is an increase in the number of provinces and districts/cities from 2 provinces and 2 cities to 34 provinces and 436 (85\%) districts / cities. The number of cases has increased from 1968 to 58 cases to 126,675 cases in 2015 (Ministry of Health, 2015). WHO noted that Indonesia was the country with the highest DHF cases in Southeast Asia where 58 people were infected and 24 of them died (Mortality Rate $=41.3$ ). Since then, this disease has spread throughout Indonesia (Achmadi et al., 2010).

The Ministry of Health of the Republic of Indonesia Directorate of Vector and Zoonotic Disease Control at the Ministry of Health stated that during January 2016 there were 3,298 dengue cases with 50 deaths in Indonesia. While in the KLB area, there were 492 cases, 25 of them died. KLB occurred in 11 districts/cities in 7 provinces. While in Central Java Province, 35 districts/cities have been infected with dengue. Incidence Rate (IR) of DHF in Central Java Province in 2014 amounted to 36.2 / 100,000 population (Profile of Central Java, Increased and spread of DHF cases was probably caused by the high population mobility, development of urban climate change, changes in population density and distribution as well as other epidemiological factors that still need further study. In addition, an increase in dengue cases each year is related to environmental sanitation conditions, this condition is exacerbated by a lack of understanding of the community about DHF and very low community parti- cipation. With the incidence of DHF, it is still considered problematic which in the home environment that looks clean, there are still conditions that can increase the risk of dengue incidence, such as open water reservoirs inside and outside the house, the presence of bushes and puddles around the house, keb the presence of used goods that can hold rainwater (Sofia et al., 2014).

DHF does not only often cause outbreaks but also has a negative impact both in terms of social and economic aspects. Social disadvantages that occur include due to panic in the family, death of family membe$\mathrm{rs}$, and reduced population expectancy (Ministry of Health, 2011). The economic impacts caused by dengue include the loss of work time, school time and the release of other costs other than for treatment, such as transportation and family expenses while maintaining patients. One of the social impacts caused by DHF is the occurrence of panic in the family and community when a dengue case occurs which causes death.

In addition, the increase in dengue cases every year is closely related to environmental sanitation conditions. This condition is exacerbated by the people's poor understanding of dengue and also very low community participation. The condition of the home environment and community behavior related to the incidence of DHF are still considered problematic which in the environment of the house that looks clean, there are still conditions that can increase the risk of dengue incidence, such as the presence of open water reservoirs inside and outside the house, bushes and puddles around the house, the presence of used goods that can hold rainwater (Sofia et al., 2014).

\section{SUBJECTS AND METHOD}

This study has received an approval from the ethics commission of the Faculty of 
Journal of Epidemiology and Public Health (2017), 2(2): 174-185

https://doi.org/10.26911/jepublichealth.2017.02.02.08

Medicine, UNS / Dr. Moewardi hospital, Surakarta No 571 / VII / HREC / 2017

\section{Study Design}

The method used in this study was field research techniques with a type of quantitative research with a case control design approach. It was implemented in May to July 2017 in the District with the highest DHF cases and the lowest DHF cases in Karanganyar District, Central Java.

\section{Population and Sampling}

The population of this study was the sample of the people in Karanganyar Regency, namely 120 subjects divided into 40 subjects with a history of DHF disease and 80 subjects with healthy criteria in Karanganyar Regency.

The sampling technique in this study was fixed disease sampling. The sampling using exclusion criteria is that if the chosen study subject moves out of town or dies then the subject of the study is replaced by another study subject. The study subjects who were less than 15 years old, then the data collection was carried out to the parents of the study subjects.

\section{Study Variable}

The independent variables in this study include age, education level, income, sanitation related behavior, and index container. Meanwhile, the dependent variable is a DHF case.

\section{Operational Definition}

The operational definition of dengue case was DHF patients in Karanganyar Regency which are stated by a statement issued by the doctor that the patient has a history of DHF and is supported by the results of laboratory tests. Age is the length of life, which is from birth until now. Age determination is done using a number of years.

The level of education is the last level of formal education that has been pursued by the study subject based on the last diploma owned.
Family income is income earned and used as a source of family economy. The behavior of environmental sanitation is the $\mathrm{h}$ abit of the community in maintaining cleanliness of environmental sanitation which includes the provision of clean water, sewage and housing. The container index is a container or place for storing clean water that is found larva/larvae of all containers examined.

\section{Variable Instruments}

The data collection techniques used in this study were questionnaire instruments that have been tested for validity and reliability to 15 study subjects, obtained results of measurements of age, education, income, sanitation related behavior, container index with total item correlation values $\geq 0.28$ and alpha cronbach $\geq 0.88$, so that all the questions are reliable.

\section{Data Analysis}

Univariate analysis was conducted to display the characteristics of study subjects and descriptive study variables. Bivariate analysis was carried out to analyze independent variables on dependent. Path analysis (path analysis) was done to analyze the effect of independent variables on the dependent variable through the intermediate variable and find out the direct and indirect effects of the independent variables on the dependent variable. The magnitude of the influence of the independent variable on the dependent variable is seen from the value of the path coefficient, the greater the path coefficient, the greater the influence given from that variable. The steps in conducting path analysis include model specifications, model identification, model suitability, parameter estimation, and model specification.

\section{RESULTS}

The results of this study explain the univariate analysis, bivariate analysis and multivariate analysis. 


\section{Univariate Analysis}

Univariate analysis consists of the characteristics of the study subject and descriptive study variables as described in table 1 .

Characteristics of study subjecs consist of gender, age, occupation, and income between case group and control group were not different except education and income (Table 2). Study subjects were more than or equal to 21 years old (controls 66.7\% and cases $33.3 \%$ ), worked outside the home (66.4\% and $33.6 \%$ ) and had income below the UMK (64.7\% and 35.3\%). The control group $62.5 \%$ of the study subjects had education levels equal to or more than high school while the case study group subjects $37.5 \%$ had less education than high school.

\section{Table 1. The characteristics of study subjects}

\begin{tabular}{|c|c|c|c|c|}
\hline \multirow{2}{*}{$\begin{array}{c}\text { Subject } \\
\text { Characteristic }\end{array}$} & \multicolumn{2}{|c|}{ Control } & \multicolumn{2}{|c|}{ Case } \\
\hline & $\mathbf{n}$ & \% & $\mathbf{N}$ & $\%$ \\
\hline \multicolumn{5}{|l|}{ Age (years) } \\
\hline$<21$ & 32 & 66.7 & 16 & 33.3 \\
\hline$\geq 21$ & 48 & 66.7 & 24 & $33 \cdot 3$ \\
\hline \multicolumn{5}{|l|}{ Gender } \\
\hline Male & 48 & 78.7 & 13 & 21.3 \\
\hline Female & 32 & 54.2 & 27 & 45.8 \\
\hline \multicolumn{5}{|l|}{ Education } \\
\hline$<$ SHS & 35 & 62.5 & 21 & 37.5 \\
\hline$\geq$ SHS & 45 & 70.3 & 19 & 29.7 \\
\hline \multicolumn{5}{|l|}{ Occupation } \\
\hline At home & 7 & 70.0 & 13 & 30.0 \\
\hline Outside & 73 & 66.4 & 37 & 33.6 \\
\hline \multicolumn{5}{|l|}{ Income } \\
\hline$<$ Minimum Wage & 44 & 64.7 & 24 & $35 \cdot 3$ \\
\hline$\geq$ Minimum Wage & 36 & 69.2 & 16 & 30.8 \\
\hline
\end{tabular}

\section{Bivariate Analysis}

Chi Square test was used to analyze the relative risk of behavior related to sanitation and container index to the incidence of DHF in Karanganyar Regency. Bivariate analysis was conducted to see the relationship of independent variables (age, education level, container index, family income, and sanitation-related behavior) and the dependent variable (DHF case) analyzed using ChiSquare test and calculation of Odds Ratio (OR) with confidence level (CI) of 95\%.
Age, education, income, sanitation-related behavior, and container index were related to the incidence of DHF (Table 2). Age $(\mathrm{OR}=1.00 ; 95 \% \mathrm{CI}=0.46$ to $2.17 ; \mathrm{p}=$ 1.00o), education $(\mathrm{OR}=0.70 ; 95 \% \mathrm{CI}=0.33$ to $1.51 ; \mathrm{p}=0.365)$, and income $(\mathrm{OR}=0.82$; $95 \% \mathrm{CI}=0.38$ to $1.76 ; \mathrm{p}=0.602$ ) the relationship is not significant, these three things increase the very weak risk of the risk of dengue cases. The results of the full bivariate analysis can be seen in Table 2. 
Journal of Epidemiology and Public Health (2017), 2(2): 174-185

https://doi.org/10.26911/jepublichealth.2017.02.02.08

Table 2. The relationship between sanitation behavior and index container with dengue incidence

\begin{tabular}{|c|c|c|c|c|c|c|c|c|c|}
\hline \multirow{3}{*}{ Variable } & \multicolumn{4}{|c|}{ DHF incident } & \multirow{2}{*}{\multicolumn{2}{|c|}{ Total }} & \multirow{3}{*}{$\mathbf{O R}$} & \multirow{3}{*}{$95 \% \mathrm{CI}$} & \multirow{3}{*}{$\mathbf{p}$} \\
\hline & \multicolumn{2}{|c|}{ Control } & \multicolumn{2}{|c|}{ Case } & & & & & \\
\hline & $\mathbf{N}$ & $\%$ & $\mathbf{N}$ & $\%$ & $\mathbf{N}$ & $\%$ & & & \\
\hline \multicolumn{10}{|l|}{ Age (years) } \\
\hline$<21$ & 32 & 66.7 & 16 & $33 \cdot 3$ & 48 & 100 & \multirow{2}{*}{1.00} & \multirow{2}{*}{0.46 to 2.17} & \multirow{2}{*}{1.000} \\
\hline$\geq 21$ & 48 & 66.7 & 24 & $33 \cdot 3$ & 72 & 100 & & & \\
\hline \multicolumn{10}{|l|}{ Education } \\
\hline$<\mathrm{SHS}$ & 35 & 62.5 & 21 & 37.5 & 56 & 100 & \multirow[t]{2}{*}{0.70} & \multirow[t]{2}{*}{0.33 to 1.51} & \multirow[t]{2}{*}{0.365} \\
\hline$\geq$ SHS & 45 & 70.3 & 19 & 29.7 & 64 & 100 & & & \\
\hline \multicolumn{10}{|l|}{ Income (Rupiah) } \\
\hline$<$ Minimum wage & 44 & 64.7 & 24 & $35 \cdot 3$ & 68 & 100 & \multirow[t]{2}{*}{0.82} & \multirow[t]{2}{*}{0.38 to 1.76} & \multirow[t]{2}{*}{0.602} \\
\hline $\begin{array}{l}\geq \text { Minimum wage } \\
\text { Sanitation }\end{array}$ & 36 & 69.2 & 16 & 30.8 & 52 & 100 & & & \\
\hline Behavior & 14 & 280 & 29 & 611 & 26 & 100 & \multirow[t]{2}{*}{5.76} & \multirow[t]{2}{*}{2.47 to 13.47} & \multirow[t]{2}{*}{$<0.001$} \\
\hline Good & 66 & 78.6 & 18 & 21.4 & 84 & 100 & & & \\
\hline \multicolumn{10}{|l|}{ Container Index } \\
\hline Flicks & 64 & 77.1 & 19 & 22.9 & 83 & 100 & 4.41 & 1.93 to 10.12 & $<0.001$ \\
\hline No flicks & 16 & 43.2 & 21 & 56.9 & 37 & 100 & & & \\
\hline
\end{tabular}

\section{Path Analysis}

Table 3 showed the result of multivariate analysis by using path analysis model. Host and environmental factors for the incidence of DHF. Path analysis was used to determine the direct or indirect effects of host and environmental factors on the incidence of DHF. Table 3 showed that sanitation conditions, sanitation-related behavior and container index significantly affected the incidence of DHF.

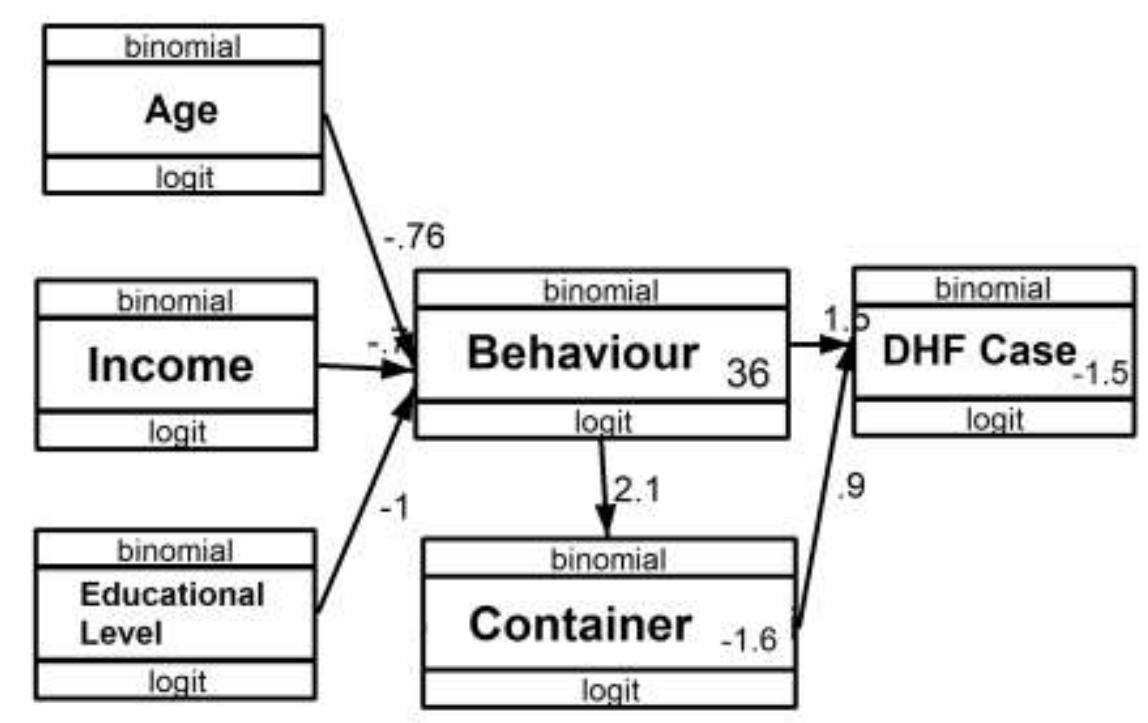

Figure 1. Structural Model with Unstandarized 
Table 3. Path Analysis Result of Sanitaion-Related Behavior and container index on the Incidence of terhadap kejadian DHF

\begin{tabular}{|c|c|c|c|c|c|c|}
\hline \multirow[b]{2}{*}{$\begin{array}{l}\text { Dependent } \\
\text { Variables }\end{array}$} & & \multirow[b]{2}{*}{$\begin{array}{l}\text { Independent } \\
\text { Variables }\end{array}$} & \multirow{2}{*}{$\begin{array}{c}\text { Path } \\
\text { Coeffi- } \\
\text { cient (b) }\end{array}$} & \multicolumn{2}{|c|}{ 95\%CI } & \multirow[b]{2}{*}{$\mathbf{p}$} \\
\hline & & & & $\begin{array}{l}\text { Lower } \\
\text { Limit }\end{array}$ & $\begin{array}{l}\text { Upper } \\
\text { Limit }\end{array}$ & \\
\hline \multicolumn{7}{|l|}{ Direct Effect } \\
\hline DHF Case & $\leftarrow$ & Container Index & 0.90 & 0.03 & 1.84 & 0.057 \\
\hline & $\leftarrow$ & $\begin{array}{l}\text { Sanitation-Related } \\
\text { Behavior }\end{array}$ & 1.50 & 0.57 & 2.42 & 0.001 \\
\hline Container Index & $\leftarrow$ & $\begin{array}{l}\text { Sanitation-Related } \\
\text { Behavior }\end{array}$ & 2.09 & 1.21 & 2.97 & $<0.001$ \\
\hline Indirect Effect & & & & & & \\
\hline Sanitation & $\leftarrow$ & Age & -0.76 & -1.60 & 0.08 & 0.074 \\
\hline Behavior & $\leftarrow$ & Education Level & -1.02 & -1.87 & -0.17 & 0.019 \\
\hline $\begin{array}{l}\mathrm{AIC}=404.42 \\
\mathrm{BIC}=429.51\end{array}$ & $\leftarrow$ & Income & -0.70 & -1.60 & 0.19 & 0.122 \\
\hline
\end{tabular}

Path analysis showed that Container Index $(b=0.90,95 \% \mathrm{CI}=0.03$ to $1.84, \mathrm{p}=$ 0.057), sanitation-related behavior $(\mathrm{b}=$ $1.50,95 \% \mathrm{CI}=0.57$ to $2.42, \mathrm{p}=0.001$ ) affected DHF cases. Sanitation-related behavior $(\mathrm{b}=2.09,95 \% \mathrm{CI}=1.21$ to $2.97, \mathrm{p}<0.001)$ has a direct effect on container index. Age $(b=-0.76,95 \% C I=-1.60$ to $0.08, p=0.074)$, educational level $(b=-1.02,95 \% \mathrm{CI}=-1.87$ to $-0.17, \mathrm{p}=0.019)$, income $(\mathrm{b}=-0.70,95 \% \mathrm{CI}=$ -1.60 to $0.19, \mathrm{p}=0.122$ ) have an indirect effect on environmental sanitation behavior through sanitation behavior.

\section{DISCUSSIONS}

\section{The Effect of Age on the Incidence of DHF}

Residents with a more mature age have a higher awareness of maintaining sanitation, and it can reduce the incidence of DHF. Wichmann et al., (2004) showed that adult DHF patients tended to have a higher severity caused by secondary infections than children patients. Adult individuals who have been exposed to or have a history of suffering from previous DHF increase the risk of secondary infections and this affected the severity of their illness.
The highest morbidity rates in DHF cases were found at the age of $15-30$ years old (Toan et al., 2015). Dung and Cam (2005) reported that more than 90\% of DHF morbidity was in the age range of 15 to 25 years old. This was related to differences in the behavior of adults and children. Adults have different lifestyle behaviors, time spent outside the house tended to be infected by dengue vectors, sleep without using mosquito nets, and children could not take preventive actions to prevent DHF (Toan et al., 2015).

\section{The Effect of Education on the Incidence of DHF}

The results of this study showed that there was an effect between the level of education on the incidence of DHF. Residents who have a higher level of education have a higher awareness in maintaining the sanitation of the environment to reduce the incidence of DHF.

The level of educations was related to knowledge. Higher levels of education lead to broader knowledge of prevention of dengue (Siregar et al., 2015). A study done by Siqueira et al., (2004) in central Brazil showed that a low level of education was assoc- 
Journal of Epidemiology and Public Health (2017), 2(2): 174-185

https://doi.org/10.26911/jepublichealth.2017.02.02.08

iated with an increased incidence of dengue infection and it was statistically significant.

The results of study conducted in Central Nepal showed that the practice of DHF prevention was related to the level of education (Dhimal et al., 2014). DBD prevention action which was based on knowledge would be more effective than actions that were not based on knowledge. The results of the study indicated that research subjects who have a good level of knowledge tend to be able to take preventive action to prevent DHF.

The result of this study was supported by a study done by Koenraadt et al., (2006) in Kamphaeng Phet Province, it was found that increased knowledge would increase the practice of reducing the number of unprotected containers/puddles, thereby reducing the environmental potential for vector breeding. With the existence of education, a person was able to obtain knowledge and implications and can provide a more rational response to the information she/he got. The ability to receive an information was strongly influenced by the level of education. The higher the level of education, the easier it was to live independently, creatively, and sustainably (Mubarak, 2007).

\section{The Effect of Family Income on the Incidence of DHF}

The results of this study residents that residents with higher incomes would be able to build healthy houses so that it would decrease the incidence of DHF.

Some research results showed that income levels negatively affected the incidence of DHF. People with low income levels and socio-economic status tend to live in environments with low capacity to provide good residents, low physical condition of the house, high density, poor sanitation, and lack of capacity to provide adequate water storage (Mulligan et al., 2015).

\section{The Effect of Behavior of Environ- mental Sanitation on the Incidence of DHF}

The results of this study showed that the behavior of residents who pay attention to the environmental sanitation reduced the incidence of DHF.

According to WHO (2012), Bruteau Index (BI) was the most informative index because it was able to show a positive relationship between the condition of the house and the existence of puddle. This index was relevant for focusing efforts to manage, control, and eliminate mosquito habitats through public health education that DHF vectors can be controlled through improved environmental sanitation to minimize the breeding places of the vector.

Was management was related to the transmission of DHF. Waste such as plastic and bottles was a place of dengue vectors. Poor management of waste could create a breeding environment for the Aedes Aegypti mosquito. The results showed that the frequency of managing waste disposal which was less than 1 time per week increased the incidence of DHF and it was statistically significant (Bohra and Andrianasolo, 2001; Cordeiro et al., 2011; Suwannapong et al., 2014).

Aji et al., (2016) and Fibriana (2004) stated that there was a relationship between the implementation of the behavior of closing, draining puddles, and hoarding used goods (3M) with the incidence of DHF. Therefore, it was recommended that people could improve the $3 \mathrm{M}$ behavior regularly to eradicate mosquito growth.

\section{The Effect of Container Index on the Incidence of DHF}

The greater the container index number, the greater the chance of developing mosquito larvae so that it increased the DHF cases. 
The result of a study done by Budiyanto (2008) showed that 182 containers were found to contain puddle, 54 containers were found to have Aedes Aegypti larvae (91\%). It was suggested that people could regularly clean the containers.

WHO (2003) stated that House Index (HI) was one of the indicators that can be used to measure the risk of disease transmission. HI can provide a percentage of positive homes and instructions on the proliferation of human populations who have risk of DHF. Containers index showed the percentage of positive containers that have Aedes Aegypti larvae. Although positive container areas have epidemiologically small numbers of Aedes Aegypti larvae, people still need to be aware because generally, Aedes Aegypti mosquitoes produced large numbers of larvae and vice versa, and it caused less risky epidemic.

The result of a study done by Fibriana (2004) showed that there was a relationship between the presence of Aedes Aegypti larvae and the incidence of DHF.

Yudhastuti (2005) stated that the density of mosquito larvae of Aedes Aegypti in Wonokusumo village was measured by using HI parameters and the score was $58 \%$, $\mathrm{CI}=30.6 \%, \mathrm{BI}=82 \%$ and $\mathrm{DF}=7$ which indicated the speed and easiness of DHF transmission.

According to Muchlastriningsih (2005) the numbers of free larvae which was less than $95 \%$ can increase the chances of dengue transmission. A study done by Fathi (2005) showed that the presence of Aedes Aegypti larvae was related to DHF and it was statistically significant.

The result of a study done by Aji et al., (2016) showed that $\mathrm{HI}=5 \%$ and $\mathrm{CI}=4 \%$. The results of the study also showed that there was a relationship between the presence of Aedes Aegypti larvae and the incidence of DHF.
Prastyowati (2013) showed that types of containers which contained Aedes Aegypti larvae include dispensers, buckets outside the house, and water reservoirs. The results of the study also showed that the activity of the Aedes Aegypti mosquito was around 18:00 to 3:00 am. both inside and outside the house.

Zulkarnaini (2008) stated that environmental sanitation conditions affected the incidence of DHF, the results of the study showed that there were positive containers with Aedes Aegypti larvae both inside and outside the house with the score of $\mathrm{HI}=$ $86.27 \%$, Container Index $(\mathrm{CI})=28 \%$, and Bruteau Index $(\mathrm{BI})=137 \%$.

The results of this study showed that there was a relationship between home environmental sanitation and the incidence of DHF. Therefore, preventive efforts were needed to control DHF vector mosquitoes through PSN activities (eradication of mosquito nests).

\section{REFERENCE}

Achmadi UF. (2010). Manajemen Demam Berdarah Berbasis Wilayah. Buletin Jendela Epidemiologi, ISSN : 20871546.

Aji R, Kamaluddin MT, Salni, Sriati (2016). Environmental factors and indices related to dengue vector larva in Rejang Lebong District. International Research Journal of Public and Environmental Health, 3 (7): 162-166. http://dx.doi.org/10.15739/irjpeh.16.021

Bhatt S, Gething PW, Brady OJ, Messina JP, Farlow AW, Moyes CL (2013). The global distribution and burden of dengue. Nature. 496(7446):504-7.

Bohra A, Andrianasolo H (2001). Application of GIS in modeling of dengue risk based on sociocultural data: Case of Jalore, Rajasthan, India. Dengue 
Journal of Epidemiology and Public Health (2017), 2(2): 174-185

https://doi.org/10.26911/jepublichealth.2017.02.02.08

Bull., 25: 92-102. https://apps.who.int/iris/handle/10665/163690

Bolarinwa OA (2015). Principles and Methods of Validity and Reliability Testing of Questionnaires Used in Social and Health Science Researches. Nigerian Postgraduate Medical Journal, 22: 195-201. doi: 10.4103/1117-1936.173959.

Chreswell JW (2012). Research Design Pendekatan Kualitatif, Kuantitatif, dan Mixed. Yogyakarta: Pustaka Pelajar.

Cordeiro RMR, Donalisio VR, Andrade ACN, Mafra LB, Nucci JC, Brown, Stephan $C$ (2011). Spatial distribution of the risk of dengue fever in Southeast Brazil, 2006-2007. BMC Public Health, 11: 10.1186/1471-2458-11-355.

Dalimunthe (2008). Faktor-faktor yang mempengaruhi partisipasi masyarakat dalam program pencegahan malaria di Kecamatan Saibu Kabupaten Mandailing Natal. Fakultas Kesehatan Masyarakat Sumatra Utara.

Departemen Kesehatan Republik Indonesia (2001). Pedoman pelaksanaan sanitasi lingkungan dalam pengendalian vektor. Jakarta: DirJen PP \& PL Depkes RI.

Dhimal M, Aryal KK, Dhimal ML, Gautam I, Singh SP, Bhusal CL, Kuch U (2014). Knowledge, attitude and practice regarding dengue fever among the healthy population of highland and lowland communities in central $\mathrm{Ne}$ pal. PloS One, 10.1371/journal.pone.0102028.g001.

Dung NT, Cam NN (2005). Dengue fever/ dengue hemorrhagic fever in Hanoi 2003. Journal of Vietnam Preventive Medicine, 1: 73-77.

Duma N, Darmawansyah, Arsunan A (2007). Analisis Faktor yang Berhubungan dengan Kejadian Demam Berdarah Dengue di Kecamatan Baruga
Kota Kendari. Jurnal Kesehatan. ISSN 0852-8144, 4(2):91-100.

Fadilla Z, Hadi UK, Setiyaningsih S (2015). Bioekologi vektor Demam Berdarah Dengue (DBD) serta deteksi virus dengue pada Aedes aegypti (Linnaeus) dan Ae. albopictus (Skuse) (Diptera: Culicidae) di Kelurahan Endemik DBD Bantarjati, Kota Bogor. Jurnal Entomologi Indonesia Indonesian Journal of Entomology, 12(1): 31-38.

Fathi T (2005) Environmental Factors Container is a factor that is very Acting Against Transmission of dengue. Purwokerto.

Fertman CI, Allensworth DD. (2010). Health Promotion Programs. USA: Jossey Bass.

Fibriana S (2004). Evaluation Process Monitoring Regional Flick Low Density (Study On Stage Lor village of Semarang).

Glanz K, Rimer BK, Viswanath K. (2008). Health Behavior and Health Education Theory, Research, and Practice. USA: Jossey Bass.

Heale R, Twycross A (2016). Validity and reliability in quantitative studies. Evidence Based Nursing. 18(3): 66-67. http://dx.doi.org/10.1136/eb-2015-102129

Kurane I (2007). Dengue Hemorrhagic Fever with Spesial Emphasis on Immunopathogenesis. Comparative Immunology, Microbiology \& Infectious Disease. 30:329-40. https://doi.org/10.1016/j.cimid.2007.05.010

Koenraadt CJ, Tuiten W, Sithiprasasna R, Kijchalao U, Jones JW, and Scott TW (2006). Dengue knowledge and practices and their impact on Aedes aegypti populations in Kamphaeng Phet, Thailand. Am. J. Trop. Med. Hygiene, 74: 692-697. 
Masic I, Hodzic A, Mulic S (2014). Ethics in Medical Research and Publication. International Journal of Preventive Medicine 5(9): 1073-1082. PMCID: PMC4192767

Masrizal, Sari NP (2015). Analisis Kasus DBD berdasarkan unsur iklim dan kepadatan penduduk melalui pendekatan GIS di Tanah Datar Jurnal Kesehatan Masyarakat Andalas http://Jurnal.Fkm.Unand.Ac.Id/Index.Ph p/Jkma/ P-Issn 1978-383 E-Issn 2442-6725 10(2)166-171. Diakses 12 Mei 2017.

Michener WK (2015). Ten simple rules for creating a good data management plan. Plos Computational Biology 11(10): 1-9. https://doi.org/10.1371/journal.pcbi.1004525

Ministry of Health of the Republic of Indonesia (2010). Buletin Jendela Epidemiologi: demam berdarah dengue.

Ministry of Health of the Republic of Indonesia (2011). Modul Pegendalian Demam Berdarah Dengue. Direktorat Jenderal Pengendalian Penyakit Dan Penyehatan Lingkungan.

Ministry of Health of the Republic of Indonesia (2012). Leaflet Cegah DBD dengan Pemberantasan Sarang Nyamuk (PSN)

Ministry of Health of the Republic of Indonesia (2013). Pedoman Pengendalian Demam Berdarah Dengue di Indonesia. Direktorat Jenderal Pengendalian Penyakit dan Penyehatan Lingkungan.

Ministry of Health of the Republic of Indonesia (2016). Kendalikan DBD dengan 3M Plus http://www.depkes.go.id/article/view/16020900002/kendalika n-dbd-dengan-psn-3m-plus.html.

Monath TP (2007). Dengue and yellow fever - challenges for the development and use of vaccines. $\mathrm{N}$ Engl $\mathrm{J}$
Med, 357: 2222-2225. Doi: 10.1056/NEJMpo707161

Muchlastriningsih S (2005) Factors Associated with incidence of dengue and Abatement Efforts in the District of West Cimanggis.Depok.Java.

Mulligan K, Dixon J, Sinn CJ, Elliott SJ (2015). Is dengue a disease of poverty? A systematic Review. Pathogens and Global Health, 109(1): 10-18. doi: 10.1179/2047773214Y.ooooooo168.

Murti B (2013) Desain dan Ukuran Sampel untuk Penelitian Kualitatif dan Kuantitatif di Bidang Kesehatan. Yogyakarta: Gajah Mada University Press.

Murti B (2016). Prinsip dan Metode Riset Epidemiologi. Surakarta: Universitas Sebelas Maret.

Nurbeti M, Jamil NA, Kuntari T, Sunarto, Ghazali HPL. (2012). Ilmu Kesehatan Masyarakat untuk Kompetensi Dokter Umum. Yogyakarta: Universitas Islam Indonesia.

Pambudi (2009). Faktor-faktor yang Mempengaruhi Partisipasi Kader Jumantik dalam Pemberantasan DBD di desa Ketitang Kecamatan Nogosari Kabupaten Boyolali Tahun 2009. Surakarta: UMS.

Penney TL, McIsaac JL, Storey K, Kontak J, Ata N, Kuhle S, Kirk SFL (2016). Examining the context of health promoting schools: A translational approach to characterization and measurement of school ethos to support health and wellbeing. BMC Public Health.

Peraginangin H, Hasim, Pramudya B, Budiarti S (2009) Potret kebijakan pengendalian demam berdarah dengue di Kabupaten Indramayu Jurnal Kesehatan Masyarakat Nasional, 4(3).

Prastyowati H (2013) Survey of Aedes larva and Nocturnal Activity SPP in Travel Market Pangandaran. 
Journal of Epidemiology and Public Health (2017), 2(2): 174-185

https://doi.org/10.26911/jepublichealth.2017.02.02.08

Profil Kesehatan Kabupaten Karanganyar (2015). Dinas Kesehatan Kabupaten Karanganyar.

Profil Kesehatan Provinsi Jawa Tengah (2014). Dinas Kesehatan Provinsi Jawa Tengah

Xu G (2007). An outbreak of dengue virus serotype 1 infection in Cixi, Ningbo, People's Republic Of China, 2004, associated with a traveler from Thailand and high density of Aedes Albopictus. Am J Trop Med Hyg, 76(6): 1182-1188.

Ramos MM (2008). Epidemic dengue and dengue hemorrhagic fever at the Texas-Mexico Border: Results of a household-based seroepidemiologic survey, December 2005. Am J Trop Med Hyg, 78(3): 364-369.

Rokim A (2017). Pengaruh faktor - faktor kondisi sosial ekonomi dan lingkungan fisik wilayah terhadap kasus demam berdarah dengue (DBD) di Kabupaten Jombang. Swara Bhumi.

Sahrir N, Ishak H, Maidin A (2016). Pemetaan karakteristik lingkungan dan densitas nyamuk aedes aegypti berdasarkan status endemisitas DBD di Kecamatan Kolaka. JST Kesehatan, 6(1): $70-75$.

Sari SK, Utama HW, Yanti I, Ranika M (2008). Pencapaian program pemberantasan penyakit demam berdarah dengue (DBD) di Puskesmas Sukarami Palembang.

Sukesi, Wahyuni T (2012). Monitoring populasi nyamuk Aedes Aegypti L. vektor penyakit demam berdarah dengue di kelurahan Gedongkiwo Kecamatan Mantrijeron Kota Yogyakarta. Jurnal Kesehatan Masyarakat (Journal of Public Health), 6(1).

Sinaga SN (2014). Kebijakan penanggulangan penyakit demam berdarah di In- donesia Jurnal Ilmiah "Research Sainis", 1(1).

Siregar FA, Abdullah MR, Omar J, Sarumpaet SM, Supriyadu T, Makmur T, Huda N (2015). Social and Environmental Determinants of Dengue Infection Risk in North Sumatera Province, Indonesia. Asian Journal of Epidemiology 8 (2): 23-35.

Siqueira JB, Martelli CM, Maciel IJ, Oliveira RM, Ribeiro MG, et al., (2004). Household survey of dengue infection in central Brazil: Spatial point pattern analysis and risk factors assessment. Am. J. Trop. Med. Hygiene, 71: 646651.

Sulaeman ES, Murti B, Waryana. (2015). Aplikasi model precede-proceed pada perencanaan program pemberdayaan masyarakat bidang kesehatan berbasis penilaian kebutuhan kesehatan masyarakat. Jurnal Kedokteran Yarsi 23(3): 149-164.

Sullivan GM (2011). A Primer on the Validity of Assessment Instruments. Journal of Graduate Medical Education 119-120.

Suresh K, Thomas SV, Suresh G (2011). Design, data analysis and sampling techniques for clinical research. Annals of Indian Academy of Neurology. 14(4): 287-290. Doi: 10.4103/0972-2327.91951

Suwannapong NM, Tipayamongkholgul AB, Boonshuyar C, Howteerakul N, Poolthin S (2014). Effect of community participation on household environment to mitigate dengue transmission in Thailand. Trop. Biomed, 31: 149158.

Suyasa (2008). Hubungan faktor lingkungan dan perilaku masyarakat dengan keberadaan vektor demam berdarah dengue (DBD) diwilayah kerja Pus- 
kesmas I Denpasar Selatan. Ecotropic 3 (1): $1-6$

Syatriani S, Puji E, Susilowati A (2009). Partisipasi masyarakat menanggulangi lingkungan demam berdarah dengue di Kecamatan Rappocini Kota Makasar Jurnal Kesehatan Masyarakat Nasional, 3(5).

Tang KF, Ooi EE (2012). Diagnosis of dengue: An update. Expert Rev Anti Infect. 10(8):895-907. doi: 10.1586/eri.12.76.

Timmreck (2004). Epidemiologi Suatu Pengantar (An Introduktion To Epidemiology) Edisi 2. Jakarta: Penerbit Buku Kedokteran, EGC.

Tavakol M, Dennick R (2011). Making Sense of Cronbach's Alpha. International Journal of Medical Education 2: 5355. doi: 10.5116/ijme.4dfb.8dfd.

Toan DTT, Hoat LN, Hu W, Wright P, Martens $P$ (2015). Risk factors associated with an outbreak of dengue fever/ dengue haemorrhagic fever in Hanoi, Vietnam, Epidemiol. Infect., 1-5. doi: 10.1017/So950268814002647.

Triwinasis S (2009) Hubungan antara praktik pemberantasan nyamuk dengan keberadaan jentik aedes aegypti di Kelurahan Parakan Kecamatan Mergangsan Kota Yogyakarta. Semarang: FKM UNDIP.

Tsai AC, Scott JA, Hung KJ, Zhu JQ, Matthews LT, Psaros C, Tomlinson M (2013). Reliability and validity of instruments for assessing perinatal depression in african settings: Systematic Review and Meta-Analysis. Plos One 8(12): 1-12. doi: 10.1371/journal.pone.0082521.

Utami RSB (2015). Hubungan pengetahuan dan tindakan masyarakat dengan kejadian demam berdarah dengue
(DBD) (Studi Di Kelurahan Putat Jaya Surabaya Tahun 2010-2014). Jurnal Berkala Epidemiologi, 3(2): 242-253.

Vandiver VL (2009). Integrating Health Promotion and Mental Health. New York: Oxford University Press.

Wanti, Darmawan M (2012). Tempat penampungan air dan kepadatan jentik Aedes sp. di daerah endemis dan bebas demam berdarah dengue. Jurnal Kesehatan Masyarakat Nasional, 9(2).

Wichmann O, Hongsiriwon S, Bowonwatanuwong C, Chotivanich K, Sukthana Y, Pukrittayakamee S (2004). Risk factors and clinical features associated with severe dengue infection in adults and children during the 2001 epidemic in Chonburi, Thailand. Tropical Medicine and International Health, 9(9): 1022-1029. Doi: 10.1111/j.13653156.2004.01295.x.

WHO (2001) Case Management Module Dengue hemorrhagic fever guidelines. Jakarta. EGC.

WHO (2003). Pencegahan dan Penanggulangan Penyakit Demam Dengue dan Demam Berdarah Dengue. Jakarta: WHO \& Depkes RI.

WHO (2003) Prevention and dengue hemorrhagic fever. Complete instructions Translation by Suroso, T. et al of Prevention Control of Dengue Haemorrhagic.

WHO (2009). Dengue. Guidelines for diagnosis, treatment prevention and control. Geneva. Diakses dari http://www.who.int/tdr/publications/documents/dengue-diagnosis.pdf) pada 3 Maret 2017.

WHO (2012). Best Practice For Dengue Prevention and Control. Geneva WHO and Ministry of Health in Jakarta. 